\title{
Capacity Building and Sustainable Development in Nigerian Universities.
}

\author{
Christian Akani \\ Lecturer, Political Science Department \\ Ignatius Ajuru University of Education, Rumuolumeni
}

\begin{abstract}
Western education was colonial in orientation. It was a veritable channel through which colonial values and colonial-Capitalist economy were transmitted to Nigeria. It was meant to produce middle-level manpower for the Colonial Order. With independence, there was less shift on the colonially - inherited system of education . But by the 1990s, it became clear that this type of education made the recipients more dependent on the society, than on their ability to create value, and unable to confront the challenges of the time. The paper seeks to examine how capacity-building in the universities can enhance sustainable development. This is because development is centered on people, and when they have the capacity and ability to recreate themselves, the quality of their lives overtime will improve. This is a qualitative research, and method of data collection was through primary and secondary sources. These include interviews, group discussions, review of existing literature, magazines and newspapers. It was discovered that the high rate of unemployment is largely because of graduates who do not have the capacity to create value and reproduce themselves productively. They depend more on the society to survive than depending on themselves. Consequently, as the burden on the society begins to deepen, the quality of life correspondingly begins to reduce. We, therefore, recommend that the curriculum of our universities should be overhauled so that its graduates will be self-reliant through entrepreneurial activity, instead of solely depending on the society for sustenance and subsistence.

Key words: Capacity building, Colonial capitalist economy, Entrepreneurial, self reliant and Sustainable Development.
\end{abstract}

\section{INTRODUCTION}

There is a growing complexity and interconnectedness of the world. This trend has almost compressed the globe into a global village, with its emerging global character, values and political economy. It has also spawned its distinct challenges, demands and expectations. Zeilig(212) noted that the real world for the vast majority of the Earth's working people is one of globalized hunger, frustration and despair. All these have made it imperative for States, institutions and peoples of the world to consciously exploit their competitive and comparative advantage in order to keep afloat. This, therefore, requires a high dose of intellectual and moral strength, and a commitment to paradigm shift. A historical shift that would equip people with the requisite competence to confront and surmount the challenges of the present epoch. Unfortunately, in this epoch driven by high-tech knowledge, most Nigerian universities seem to be in a quandary as they have been caged in the catacomb of backwardness. The opportunity to produce human capital that would be the vanguard of technological development becomes very slim. Their paralysis of will and poor official attention to continuous education have led to a development stagnation. The aftermath is that they find it difficult to accomplish their statutory responsibilities, and keep recycling ideas that have lost touch with reality. It is therefore, not strange that many Nigerian now find solace in universities outside the shores of the country. It is no more news that Nigerians pay the sum 
of $\$ 150$ billion annually on school fees outside. This portends a bleak future for the country, especially as the 'Giant of Africa', and as the world is on the fast lane of technological development in which only those who have the competence and social capital can survive and compete favorable. In this scenario, those who cannot, only become onlookers and are reduced to an insignificant extra. They would be made to wear the toga of subservient mentality. It is against this backdrop that we shall examine how capacity building can ensure a sustainable development in Nigerian universities.

\section{CONCEPTUAL FRAMEWORK}

It will be opposite at this juncture to clarify some of the concepts that will be used in this study. This will make for a clear comprehension and objectivity of the analysis.

\section{What is Capacity Building?}

Capacity building is one of the concepts in the social sciences that cannot be subjected to a strait definition. This is because of its appeal and meaning to different people at different times. Locke (1959) stated that human beings were born without innate ideas, but as they started interacting with the society, they began to gradually gain social consciousness and knowledge. For him, therefore,

I allow therefore, a necessity that men should come to the use of reason before they get the knowledge of those general truth, but deny that men's coming to the use of reason is the time of their discovery (Locke, 1959:46).

Acquisition of consciousness is an integral part of capacity building. It is the rudimentary stage and beginning of equipping people to ensure the realization of their potentials and guarantee of human flourishing. Kostantinov (1979:360) noted that social consciousness and individual consciousness are constantly interacting and enriching each other. Every individual throughout his life, through relationships with other people, through education and training, experiences the influence of the social consciousness, although his attitude towards this influence is not passive but active and selective. Consciousness as part of capacity building is governed by social laws. The United Nations Development Programme (UNDP) defined capacity building as a long-term continual process of development that involves all stakeholders including ministers, local authorities, non-governmental organizations, community members, academics and more. Poelzer (2012) defined it as the process and goals of strengthening human potentials in the participation of public decision-making and achievement of public goals within the constraints of the society, political, economic and national environment. Capacity building is largely focused people and institutions for sustaining order and good governance. It takes for granted that popular participation is primary if society must reproduce itself, and to deny the people the capacity to exploit their natural potentials is to lay the foundation for the extinction of humanity. This is why, it is seen mainly as a process that starts from the principle that people are best empowered to realize their full potential when the means of development are sustainable.

It is a home-grown and long-term policy, generated and managed collectively by those who stand to benefit (Tavanti, 2011). As the society is in an unending dialectical movement, with its complexities for excellence and perfection, there is the necessity to equip human capacity so that it can adjust and respond proactively to the changing time. This is why the United Nations Environment Programme (UNEP) defines it, as building capacities, abilities, relationships and values that will enable organizations, groups and individuals to improve their performance and achieve their development objectives. The underlying fact is that development would elude a people vegetating according to the tide, and less interested in updating their capacity. We can deduce from the above that capacity is linked with human freedom. Ability to recognize and 
protect ones basic freedoms is the beginning and starting point of development. Development is an essential part of human rights, but it cannot blossom without human ability and capacity to recognize and work towards it. In fact, without this capacity, humanity will be subjected to the tyrannical instinct of despotic rulers. The 2002 UNDP Report clearly stated that political freedom and the ability to participate in the life of one's community are capabilities that are as important for human development as being able to read and, write and being in good health. People without freedom have far fewer choices in life. From our discourse thus far, we can deduce that capacity building involves the following;

a) It is a catalyst and constant trigger of change in the society.

b) It is necessary for strengthening and building social institutions.

c) Not limited to particulars, but open to a wide range of different groups in the society.

d) Cannot be separated from fundamental rights of man.

Capacity building fills the individual with hope, courage and sense of pride to face challenges without exogenous aid. It emboldens its recipient with a self-reliant flair, abhors aid-dependent mentality and inferiority complex. While the individual is always aiming higher, and building positive values, the institutions are gradually growing stronger and ready to stand the text of time. Within this milieu, strong institutions are presided over by people with the ability, capacity and competence to discharge their responsibilities, and ensure the triumph of sustainable development.

\section{What is Sustainable Development?}

Sustainable development is made up of two verbs. Sustain and development. Let us look at development. It was the Report of the World Commission on Environment and Development (The Brundtland Commission) that popularized the concept. It noted that sustainable development is development that meets the needs of the present without compromising the ability of future generations to meet their own needs. It is meeting the essential needs and aspirations of humanity without necessarily putting the future in jeopardy.

It is a new way of life and approach to social and economic activities for all societies rich and poor which is comparable with the preservation of the environment (Oyeshola, 2008:160).

Apart from the protection and promoting the needs of people, it also places a constraint on the activities of people so that the future cannot be consigned to a percipience. The focus of sustainable development is to satisfy the immediate needs, and at the same time make provision for future generation. It is an affirmation of what may be called system thinking. The realization that our action has the capacity to affect others because we are living in a world of interconnectedness has made a desideratum for human environment to be judiciously used, preserved and protected.. This is the hallmark of environmental preservation and justice. Oyesbola (2008:162) stated that

environmentally sustainable system must maintain a stable resource base, avoiding over-exploitation of non-renewable resource systems or environmental sink functions and depleting non-renewable resources only to the extent that investment is made adequate substitutes.

The importance attached to sustainable development made the UN to establish an office of Sustainable Development (UNOSD) in 2011. The office is expected to assist member states of UN in four major ways.

1. Facilitating knowledge exchange 
2. Carrying out research and policy analysis

3. Proving opportunity for capacity building

4. Assist to form and nurture networks and partnerships

The UN has also organized myriad conferences aimed at mainstreaming sustainable development in the policies and programmes of member states. These include the Stockholm, Sweden conference, September 5-16, 1972. This was the first international response against environmental degradation. The conference was aimed at finding a common outlook and common principle to inspire and guide the people of the world in the preservation and enhancement of the human environment (Oyeshola, 2008:38). The UN Conference on Environment and Development (UNCED) in Brazil otherwise known as Rio conference, June 3, 1992, World Commission on Environment and Development, 1987, the Kyoto, Protocol conference of 1997 and the Earth Summit 11, 2012. These conferences were directed at protecting the environment for future use, while supporting human development. For instance, the Kyoto protocol called for a target reduction of carbon dioxide to at least $5 \%$ by the industrial countries between 2008 and 2012 to reduce green house effect.

\section{State of Nigerian Universities}

Western education in Nigeria and Africa was a colonial creation. Its policy focus, curriculum and ideological base was to produce the much needed manpower for the colonial state, and prepare Africans through evangelism for the total acceptance of western values. As the colonized were perceived to be a sub-specie of humanity, western education would raise them to an acceptable standard so that they can work as clerks, civil servants, interpreters and clergy men. The educated Africans were seen as self-deprecating black-skinned Europeans, and as docile tools of settler colonialism whose highest ambition was to live like the settler whose image he had been molded (Collins, 2007:216). It was not amazing that colonial education was vilified and condemned by Africans because of its hollow content, and alienated, it the recipients from their environment. It was against this backdrop that Ekekwe (1986:37) posited that colonial education was the ideological groundings of the colonial state. It was aimed at consolidating the raciocultural superiority of the white race (Collins 2007:213). In Nigeria the missionaries pioneered the spread of education. It was a medium which also facilitated Christian evangelism as the different Christian missions competed for converts. Unfortunately, the colonial state displayed a lukewarm attitude in the expansion of education. The development of tertiary education was a precipitate of three commissions. The first commission was headed by Walter Elliot in 1943. Among the members was the President of the Nigerian Union of Teachers (NUT), Rev. Ransome Kuti, the Asquith commission and the commission headed by Eric Ashby in 1958. The recommendations of these commissions heralded an avalanche of universities in Nigeria. For instance, the recommendations of the Elliot and Asquith commissions led to the establishment of university college, Ibadan in 1948. The Ashby commission laid the groundwork for the establishment of many universities, and the setting up of a National University Commission (NUC) through Decree No. 1 of 1974. The Decree empowered NUC to administer the Nigerian University System. Ekekwe (1986:37) noted that it was after the 1920s that the colonial state showed interest in education for Africans, by establishing in 1920 the Yaba Higher College and in 1948, the university college, Ibadan. The College was affiliated to University of London Pursuant to the recommendation of the Ashby commission, from 1966, five universities were established, namely, university of Lagos, University of Nigeria Nsukka, Ahmadu Bello University, University of Ife now Obafemi Awolowo University and University College Ibadan became a full university. It is interesting to note that the new universities did not deviate from the ideological orientation of the colonial era. The recipients saw themselves as products of ivory tower and the rightful inheritors of the munificence and social aura left by the colonialists. Ostensibly, this 
was bound to dichotomize the society between receivers and non-receivers. Kwame Nkrumah, first president of Ghana noticed this trend when he declares that the ivory tower concept of university is dead. If reforms do not come from within, we intend to impose them from outside seeing that our university is a healthy university devoted to Ghana interest (Akubue and Enyi, 2001:8). Nzimiro (2006:15) noted that the crisis of the Nigerian social sciences could be traced to the orientation of the pioneer universities that implicitly subscribed to the liberal bourgeois functionalist social sciences, and preferred to be portraying pure science. He said that in Nsukka, Ife, Lagos, Zaria and Benin faculties Social Sciences were sponsored by western liberal social scientist who insidiously had a stake in the intellectual attitude of the western liberal capitalist order (Nsimiro, 2006:15). By the time the military took over political power from the civilians, it was clear that the universities would be on a cascade of decadence. They compounded the crisis which Nzimiro (2006) highlighted. The Private Universities Abolition and Prohibition Decree No. 19 of 1984 was repealed, and the Education Minimum Standards and Establishment of Institutions Decree No. 16 of 1985 was promulgated. This led to a university explosion in the country. From 2 universities in 1960, by the $21^{\text {st }}$ century, there are about 90 universities including Federal, State and Private with millions of students intake. Regrettably, these universities, especially the State and Federal were starved of needed funds, values hostile to university environment were introduced. The social instability on campus forced students to display their barbaric antics which led to needless death of many staff and students. It was, therefore not strange that from the 1990s, there were palpable signs that Nigerian universities were on the brink of collapse. According to Attahiru Jega, former National President of the Academic Staff Union of Universities (ASUU),

the military regimes which dominated the Nigerian state in particular, have pesided over a situation in which there is a systematic decline of public spending on education while military expenditures have sky-rocketed (Okoh, 2000:41).

It is a historical fact that the Nigerian ruling class including those in the military consistently denied and deprived university education the financial resources to do what was expected of them, especially in teaching and research which would booster the development agenda of the country. Instead, they engaged in mindboggling primitive accumulation of wealth. This is in spite of their populist pretensions and false concern about education. It is, therefore, not surprising that since 1986 to 2012, allocation to education has been negligible, even far below the United Nations Education Scientific and cultural organization (UNESCO) benchmark of 26\% of national budget (see table 1).

Table 1: Federal Government yearly allocation to education 1986-2012

\begin{tabular}{|l|c|}
\hline Year & Allocation to education as \% of total \\
\hline 1986 & 1.95 \\
\hline 1987 & 1.25 \\
\hline 1988 & 1.65 \\
\hline 1989 & 6.8 \\
\hline 1990 & 7.1 \\
\hline 1991 & 3.64 \\
\hline 1994 & 7.83 \\
\hline 1995 & 12.96 \\
\hline 1996 & 12.32 \\
\hline 1997 & 11.59 \\
\hline 1998 & 10.27 \\
\hline
\end{tabular}




\begin{tabular}{|l|l|l|l|}
\hline \multicolumn{1}{|c|}{ Year } & \multicolumn{1}{|c|}{ Annual Budget(N) } & \multicolumn{1}{|c|}{$\begin{array}{c}\text { Allocation to } \\
\text { Education(N) }\end{array}$} & \multicolumn{1}{|c|}{$\begin{array}{c}\text { FGN Release } \\
\text { \% }\end{array}$} \\
\hline 1999 & $60,510,335,647$ & $2,700,100,000$ & 4.46 \\
\hline 2000 & $413,119,720,860$ & $29,514,932,709$ & 7.14 \\
\hline 2001 & $894,214,805,186$ & $38,983,776,900$ & 4.36 \\
\hline 2002 & $1,064,801,253,520$ & $51,335,499,300$ & 4.82 \\
\hline 2003 & $976,250,543,375$ & $61,726,621,039$ & 6.82 \\
\hline 2004 & $1,302,523,844,588$ & $7,217,886,839$ & 5.54 \\
\hline 2005 & $1,799,938,28$ & $92,594,739$ & 5.14 \\
\hline 2006 & $1,900,000,00$ & $166,600,000$ & 8.77 \\
\hline 2007 & $2,309,233,93$ & $189,199,79$ & 8.19 \\
\hline 2008 & $2,453,639,99$ & $210,444,879$ & 5.58 \\
\hline 2009 & $3,101,813,76$ & $184,671,736$ & 6.98 \\
\hline 2010 & $4,608,000,00$ & $295,300,000$ & 6.42 \\
\hline 2011 & $4,226,000,00$ & $304,300,00$ & 8.40 \\
\hline 2012 & $4,877,209,13$ & $400,153,000$ & 8.43 \\
2016 & $6,08 \operatorname{tr}$ & N369.6 billion & 6.1 \\
\hline
\end{tabular}

Source: Akani, C (2011), Okolie, A.M. (2015).

From the table, we can see that the percentage allocated to education was negligible, and very far from the UNESCO benchmark. This account for the perennial crisis in Nigerian educational system

Okolie (2015:168-9) also noted that out of twenty African countries, Nigeria had the least budgetary allocation of $8.4 \%$ to education, and occupies the twentieth. Position, with Ghana first with $31.0 \%$. Nigeria also occupies the last position out of twenty African countries whose population is living below $\$ 1.25$ and $\$ 2$ per day. While 64.4 million Nigerians are living under $\$ 1.25$ per day, 83.9 millions are living under $\$ 2$ per day (Okolie, 2015:10-1). This detestable scenario is compounded by the growing graduate unemployment and underemployment in the country.(see table11).

Table 11: Unemployment Rate in Nigeria 2008-2012 Male and Female.

\begin{tabular}{|c|c|c|}
\hline Year & $\begin{array}{c}\text { Percentage of Unemployed } \\
\text { of Youth Female }\end{array}$ & $\begin{array}{c}\text { Percentage of } \\
\text { Unemployed Youth Male }\end{array}$ \\
\hline 2008 & 58.50 & 54.68 \\
\hline 2009 & 57.82 & 50.77 \\
\hline 2010 & 54.52 & 47.59 \\
\hline 2011 & 50.85 & 59.93 \\
\hline 2012 & 55.42 & 53.25 \\
\hline
\end{tabular}

Source: NISERA, 2013

From the table above, we can see that the number of Youth unemployment is very high in the country with females toping the number. This account for the brazen prostitution, human trafficking, social discontent and rising frustration among the Youth. This pitiable condition is made worse by the more than 10.5 million out of school children, 
systemic corruption, resource - related conflicts and the dreaded Boko Haram insurgency. For more than 552 days, the 276 abducted Chibok girls by the terrorist organization has not been released. According to the National President, Nigerian Union of Teachers, Mr Michael Olukoya, over 600 teachers were killed in the Northeast, and 19,000among the Internally Displaced Persons(IDPs). This is in addition to many schools destroyed by Boko Haram since 2014.(The Nation Newspaper, October 6,2015) Naanen (2015:44) estimated that Nigerian elite stole between 400 billion to 600 billion dollars between 1960 and 1999, and that the amount stashed in foreign accounts rose from 50 billion dollars in 1999 to 170 billion dollars in 2003. Public officers no longer consider it a disdain and debasement of human values to steal and amass unmerited wealth with impurity. According to Transparency International, since 2011 to 2014, Nigeria has been occupying a high position on the corruption ladder. In 2011,out of 183 countries, Nigeria occupied 143 position on the corruption table. In 2012, the position was139 out of 176. In 2013, the country ranked 144 out of 177 and in 2014 it ranked 136 out of 176 countries(The Nation Newspaper, December 2, 2015).The net effect of all these dismal picture is that Nigerian universities are wobbling and can hardly find their bearing. Most of the faculty staff can be described as intellectual giants, but moral dwarfs with corrosive legacy of avarice and depravity. Prof. Ayo Banjo, former Vice Chancellor of university of Ibadan lamented that

Just what are the graduates getting out of university education these days in terms of improvements both to the quality of their minds and more importantly to their character? ... we are now frankly worried about the quality of the average graduate produced, given the present state of our libraries and laboratories (Okoh, 2000:51).

Today, most Nigerian universities have no equipped library, hardly sponsor staff and students to local and international conferences. This is in spite of the effusions of NUC and the Tertiary Education Trust Fund (TETFUND). Some students' hostels are infested with bedbugs like that of Lagos State University, dingy, with poorly designed classrooms. The library and laboratories which should be the hub of the academic system in most cases are allowed to decay due to nonuse or books are out of turn with reality. All these handicap have greatly reduced the capacity of Nigerian universities to be the heart of society by eminently playing their roles in research and learning, and education of real knowledge or the acquisition of real knowledge (Okoh, 2000:103), so that it can have the competitive advantage to aspire for excellence in the $21^{\text {st }}$ century. More worrisome is the fact that, despite efforts being made by the Government, out of the 90 universities in the country, no one was worthy to be among the top 100 in the 2014/2015 Time Higher Education World University Ranking .Of the top 50 universities in Africa, only 4 Nigerian Universities were listed. These include, university of Lagos (UNILAG) $20^{\text {th }}$ position, Obafemi Awolowo University (OAU) $23^{\text {rd }}$ position, university of Ilorin (UNIIlorin) $41^{\text {st }}$ position and covenant university $43^{\text {rd }}$ position. Covenant university is one of the privately owned universities in Nigeria. With a university that is adrift, without the minimum benchmarks for institutional capacity building, given a tokenistic resource allocation and bereft of the state-of-the-art websites that is necessary for a functional and dynamic university system, it is not strange that the leadership is in most cases purposeless, visionless and inept (Iyayi, Oshio and Okojie, 2011:48). Most of the time internal schism among principal officers of the university for plum jobs and choice positions divert attention to hopeless ventures, and unwittingly derail the vision of the university. In this chaotic environment, it becomes an uphill task for students to be the vanguard of change in the society. They perform as robots, denied of systematized extra-curricula programmes, only waiting to get their certificates. They enter the school raw, without passing through the university, vice versa, without any added value. For them, university education starts and ends in passing exam by all means possible. With little or no capacity and entrepreneurial skill they become liabilities to the society and pile up the rising discontent in the society. This sad situation have made our universities loose the 
foresightedness and purposefulness to beam the light for sustainable development in the $21^{\text {st }}$ century. Although, the Central Bank of Nigeria (CBN) has through its university Capacity Building Programme given the sum of $\$ 453$ million as grants to 24 universities for infrastructural development, considering the enormity of the decadence, this seem to be a tip of the iceberg.

\section{Capacity Building in the Universities}

In view of the deplorable and despicable condition, Nigerian universities have found themselves, capacity building becomes the surest way of repositioning them so that they can be the beacon of sustainable development in the society. This is of uppermost importance because university education plays a critical role in training individuals to more effectively implement new technologies, to use innovative approaches to establish and manage more difficult enterprises and institutions, and to use resources more effectively (Iyayi, et al, 2011:41).

Capacity building is the process of institutionalizing training and retraining. It is an essential component of equipping the university to surmount immediate challenges and re-strategize to subsist, and reproduce itself in the face of future complexities. It is preparing to become relevant at all times without being subservient, and playing a second fiddle in the business of knowledge production. China's global breakthrough is hinged on its investment in capacity building. In fact, their Agenda 21 declared that the development of education is fundamental to sustainable development. China's robust attention to capacity building of its students has been responsible for its global breakthrough. Jacques(2012;548) declared that' it seems likely that Chinese innovation will over the next two decades rise steadily up the global rankings to eventually occupy positions within the top ten'. President Obama's 2008 presidential acceptance speech vowed to 'provide every child a decent education'. Capacity building in Nigerian universities will in all honesty strengthen the internal institutions to be forward-looking, success-driven, broaden the resource base of the university by collaborating with other universities and build the capacity of the staff to engage in researches that will attract international attention and grants to the school. This is the paradigm shift which must affect the focus, function and direction of universities.

The university council becomes the fulcrum for this turn around.

The University Miscellaneous Provisions Amendment Act 2003 stated that the governing council of a university shall be free in the discharge of its functions and exercise of its responsibilities for the good management, growth and development of the university (Iyayi, et al, 2011:143).

For the council to perform these responsibilities, it must be committed to the ideal of a university. University Councils should not be a to compensate politicians who want to recoup money lost during electioneering campaigns. It must be made up of competent people, and those who have the flair for enlightenment. They must ensure a good corporate governance and lay down a broad policy that must place the university on the pedestal of excellence and self-reliance. This will presuppose a leadership that is ardently committed to innovation, transformation and change. A university with a static vision and leadership will automatically become an albatross on the society. Therefore, capacity building cannot work on itself without a transformatory leadership at all levels.

Transformational leadership entails listening, speaking and acting in a manner that mobilizes self and others to take concrete action to realize a common vision (Iyayi, et al, 2011:134). 
This suggest that members of the university must subscribe to the philosophy of the citadel of learning. It must not be a cover for those who do not have the university flair to hide and perpetuate anti-social antics. Regular conferences at all levels should be vigorously pursued with extra-curricula trainings in sports, leadership training, and entrepreneurial mentoring should be encouraged. The practice of honouring students who have distinguished themselves in academic work at the department and faculty levels should be encouraged. The students must be made to know that university education is not and must not be for passing exams or a painful experience, but an opportunity to improve their capacity and competences so that they can be self-reliant and contribute to the sustenance of the society. The colonial mindset that university certificate is a 'meal ticket' should be jettisoned because the reality is at variance with such mindset In this epoch of globalization, Nigerian universities must begin to reevaluate how they can become relevant in the unfolding global order. They must close ranks and build their capacities in all facets to transcend their inadequacies if they want to be taken seriously in the change mantra in the country. Most importantly if they want to be counted among the 'producers of knowledge and ideas' in the globe, capacity building should be mainstreamed in their policies.

\section{CONCLUSION AND RECOMMENDATIONS}

In this paper we have discovered that capacity building entails propping the abilities of institutions and individuals so that they can contribute to the development of their environment. Capacity building is an essential part of human society, and must be encouraged to secure the future. While individual potentials are constantly equipped to face the challenges of the time, they are positioned to reproduce themselves in a positive manner such that selfreliance becomes their goal. This lies the connection between human freedoms and sustainable development. As humanity begins to build their competences, their capacity to recognize, protect and promote their rights is enhanced and this lays the foundation for sustainable development. Sustainable development takes care of the needs of today without compromising the future. Here lies the urgent call for environmental justice which is the central focus of all UN conferences on Environment Development. Development is geared towards raising the quality of life of a people, empowering them to take decisions favoring them and enhancing their freedoms as individuals. Therefore, sustaining development is an affirmation that tomorrow is as important as today, and to bind tomorrow is to consign today to an abyss of disorder. Nigerian universities as they are presently constituted cannot be the heart of society to pioneer sustainable development and give service to the society. This is because it is seriously confronted with centrifugal forces which combine to derail its focus, and limits its capacity to be among the best in the world. In this scenario, its students are half-baked, at war with themselves and the society, because the illusion of having a university certificate becomes clearer during life after university. The university environment is not convenient for research and having and this compound the crisis of the students who remain unrefined, raw and incapable of adding value to the society in spite of university socialization. Okunne (2000) declared that even the best degree holders can turn out to be a disgrace to the system if not given the right attitudinal orientation. Capacity building for sustainable development in the universities becomes a desideratum. With the complex nature of the global environment, it has become complex nature of the global environment, it has become urgent that Nigerian universities must be repositioned to play their vanguard role of manpower development and 'manufacture' of knowledge that will equip the university to re-strategize and overhaul its compartment. This will entail massive training and retraining. Ensuring a good corporate governance through a transformational leadership that will elicit the support of the minutest component of the university in the accomplishment of its goal. All the institutions in the university starting from the Council, senate to committee level must be manned by competent and transparent people whose conduct must be in consonance with the university ideal of 
excellence. It has been discovered that some members of these institutions are most often politicians whose appointments represent a compensation for political deeds. They become conduits through which corrupt practices are perpetrated. In some cases, they are weak to control the excesses of some overzealous Vice Chancellors. While it cannot be disputed that government has been supporting university education through statutory allocation from NUC, TETFUND, and Tertiary Education Tax (TET), these have not been judiciously utilized for the purpose for it was approved. The systemic corruption in the Nigerian political economy has made it difficult for training of manpower to be vigorously pursued. Many lecturers cannot attend conferences because assessing funds from their school is like a camel passing through the eye of a needle. It is therefore, possible to see lecturers whose horizon is limited and this affect their delivery and self-reproduction. In cases where money is approved primordial consideration plays a major role.

In conclusion, therefore, if the Nigerian state want universities to join their counterpart in shaping the world of knowledge, it must ensure that there is an unreserved commitment to capacity building. To do otherwise is to eclipse the future, for darkness and backwardness.

\section{References}

Akabue, A.U. and Enyi, D. (2001). Crises and Challenges in Higher Education in Developing countries. Ibadan: Wisdom Publishers Limited.

Akani, C. (2011). Political Economy of Secret Cults in Nigerian Universities. Abraka: Delta State University.

Collins, R. (2007). Historical Problems of Imperial Africa. Princeton: Markus Wilnner Publishers.

Ekekwe, E. (1986). State and Class in Nigeria. Lagos: Longman.

Iyayi, F., et al (2011). Critical issues in University Governance in Nigeria. Lagos: Malthouse Press Limited.

Jacques,N(2012) When China Rules the World. Penguin Books, London

Konstantinov, F.U. (1979). The Fundamentals of Marxist-Leninist philosophy. Moscow; Progress Publishers.

Locke, J. (1959). An Easy concerning Human Understanding. New York: Dover Publications Inc.

Naanen, B. (2015). The Prosperity and Poverty of Nations. Using Global Models to Explain and Mitigate Underdevelopment in Nigeria. Inaugural Lecture series No. 119, University of Port Harcourt, Choba.

Nzimiro, I. (2006). The crisis in the social sciences. The Nigerian Situation. Oguta: Zim Pan African Publishers.

Okoh, J.D. (2000). University Education, Democracy and Development in Nigeria. Port Harcourt: University of Port Harcourt Press.

Okolie, A.M. (2015). Norms and Practices in Global Political Economy. Berlin, Galda Verlag.

Oyeshola, O.P. (2008). Sustainable Development Issues and Challenges for Nigeria. Ibadan: Daily Graphics Nig. Ltd.

Poelzer, G. (2012). Capacity Building and Sustainable Development Comparative Lessons and the Russian North. International Centre for Northern Governance and Development. University of Saskatchewan.

Report of the United Nations Development Programme,2002. 